\title{
Cloning of a Thermostable $\alpha$-Amylase Gene from Thermomonospora curvata and Its Expression in Streptomyces lividans
}

\author{
By MIROSLAV PETŘíČEK, KAREL STAJNER AND PAVEL TICHÝ* \\ Department of General Microbiology, Institute of Microbiology, Czechoslovak Academy of \\ Sciences, Vídeňská 1083, 14220 Prague 4, Czechoslovakia
}

(Received 17 April 1989; revised 24 July 1989; accepted 6 September 1989)

The gene from Thermomonospora curvata CCM 3312 coding for thermostable $\alpha$-amylase (tam) has been cloned in Streptomyces lividans TK 24 and localized to a $2.6 \mathrm{~kb}$ HindIII-BamHI fragment of DNA. The data presented here show that the tam gene is expressed at a high level in $S$. lividans and that the protein is efficiently excreted.

\section{INTRODUCTION}

Interspecific cloning of Streptomyces genes coding for polysaccharide-degrading enzymes has been reported in several papers. Using streptomycete plasmid vectors, genes coding for endoglycosidase $\mathrm{H}$ from $S$. plicatus (Robbins et al., 1981), agarase from $S$. coelicolor (Kendall \& Cullum, 1984; Bibb et al., 1987; Buttner et al., 1987), $\alpha$-amylase from S. hygroscopicus (McKillop et al., 1986; Hoshiko et al., 1987) and S. limosus (Long et al., 1987, Virolle \& Bibb, 1988), and endoglucanase from Streptomyces no. 36a (Iwasaki et al., 1987) and S. lividans (Shareck et al., 1987) have been cloned and expressed in streptomycetes. There have been two reports concerning the successful intergeneric transfer of genes coding for polysaccharide-degrading enzymes from Thermomonospora fusca in S. lividans. These are the genes coding for endocellulase $\mathrm{E}_{2}$ (Ghangas \& Wilson, 1988) and endocellulase $\mathrm{E}_{5}$ (Ghangas \& Wilson, 1987). The transfer of genetic material between Thermomonospora and Streptomyces in the opposite direction was demonstrated by transfer of the Streptomyces plasmid pIJ702 from S. lividans to $T$. fusca protoplasts (Pidcock et al., 1985).

Members of the genus Thermomonospora, facultatively thermophilic actinomycetes, play an important role in decomposition of organic compounds in composting plant material (Goodfellow \& Cross, 1984). This genus includes sugar-degrading actinomycetes which can utilize a wide variety of plant sugars and polymeric carbohydrates as carbon and energy sources (Crawford et al., 1973; Bellamy, 1974, 1977; Hägerdal et al., 1980). The family Thermomonosporaceae shows a specific, but not close relationship to the Streptomycetaceae (Stackenbrandt \& Schleifer, 1984). With respect to genetic relationship and similarities in its secretion of extracellular hydrolytic enzymes, it appears to be an appropriate source of genetic material for cloning in streptomycetes.

Another example of intergeneric transfer of genetic material between Thermomonospora and Streptomyces species is described in the present work. The gene coding for thermostable $\alpha$ amylase in $T$. curvata, an enzyme which has already been purified and characterized (Stuzenberger \& Carnell, 1977; Glymph \& Stuzenberger, 1977), was cloned in streptomycete plasmid vectors and expressed in S. lividans.

\section{METHODS}

Bacteria and plasmids. These are listed in Table i. With the exception of T. curvata, the manual of Hopwood et al. (1985) contains details of conditions for growth of bacterial strains, as well as methods for plasmid and chromosomal DNA isolation and their use in transformation.

Abbreviation: CIAP, calf intestinal alkaline phosphatase. 


\section{Table 1. Bacterial strains and plasmids}

Strains and plasmids

Thermomonospora curvata CCM 312

Streptomyces lavendulae 1080

Streptomyces lividans

TK 24

pIJ61

pIJ487

pIJ622

pRS410

pRS416

pRS418

pRS419

pRS420

pRS421

pRS417

pRS422
Relevant characteristics

Thermostable $\alpha$-amylase

$\left(\mathrm{Tam}^{+}\right)$producer

$\mathrm{Sm}^{\mathrm{r}}$ SLP2- SLP3-

$\mathrm{Ts}^{\mathrm{r}} \mathrm{Nm}^{\mathrm{r}}$

Ts', promoterless aph gene (promoter-probe plasmid)

Ts $^{\mathrm{r}} \mathrm{Mel}^{+}$; pIJ702 derivative

Plasmid vector; $\mathrm{Nm}^{\mathrm{r}} \mathrm{Ts}^{\mathrm{r}}$

(pSLG33 replicon)

Recombinant plasmid

$\mathrm{Tam}^{+} \mathrm{Ts}^{\mathrm{r}}$ (pIJ61 replicon)

$\mathrm{Tam}^{+} \mathrm{Ts}^{\mathrm{r}}$ Deletion

$\left.\mathrm{Tam}^{+} \mathrm{Ts}^{\mathrm{r}}\right\}$ derivatives

$\left.\mathrm{Tam}^{-} \mathrm{Ts}^{\mathrm{r}}\right\}$ of pRS416

Recombinant plasmid

$\mathrm{Tam}^{+} \mathrm{Ts}^{\mathrm{r}}$ (pIJ487 replicon)

Recombinant plasmid

$\mathrm{Tam}^{+} \mathrm{Ts}^{\mathrm{r}}$ (pIJ622 replicon)

Recombinant plasmid

$\mathrm{Tam}^{+} \mathrm{Ts}^{\mathrm{r}}$ (pRS410 replicon)

\section{Source/reference}

Czechoslovak Collection of Micro-organisms Institute of Microbiology, Moscow

John Innes Institute

(Hopwood et al., 1985)

John Innes Institute

(Thompson et al., 1982)

John Innes Institute

(Ward et al., 1986)

John Innes Institute

(T. Kieser, unpublished)

M. Petříček (unpublished)

This work

This work

This work

This work

This work

Media. T. curvata CCM 3312 was grown in liquid medium with the following composition: $0 \cdot 2 \%(\mathrm{w} / \mathrm{v})$ $\left(\mathrm{NH}_{4}\right)_{2} \mathrm{SO}_{4}, 0.02 \% \mathrm{MgCl}_{2}, 1 \mathrm{mM}-\mathrm{CaCl}_{2}, 10 \mathrm{mM}-\mathrm{K}_{2} \mathrm{HPO}_{4}, 0.1 \%$ yeast extract (Oxoid), $1 \%$ soluble starch (Lachema); pH 8.0 at $53{ }^{\circ} \mathrm{C}$.

The medium used for sporulation of $T$. curvata (SPTC) contained : $0.05 \% \mathrm{MgSO}_{4} .7 \mathrm{H}_{2} \mathrm{O}, 8 \mathrm{mM}-\mathrm{K}_{2} \mathrm{HPO}_{4}, 0.05 \%$ glucose, $0.5 \%$ yeast extract (Oxoid), $1 \%$ crystalline cellulose, $1.7 \%$ agar and $0.2 \mathrm{ml}$ trace element solution (Hopwood et al., 1985) per $100 \mathrm{ml}$ SPTC; pH 8.0.

BA agar medium was used to screen for $\alpha$-amylase-producing colonies: 0.05 M-potassium phosphate buffer $\mathrm{pH}$ $7.2,0.02 \% \mathrm{MgSO}_{4} .7 \mathrm{H}_{2} \mathrm{O}, 0.1 \%$ yeast extract (Oxoid), $1 \%$ soluble starch (Lachema), $1.5 \%$ agar, $0.2 \mathrm{ml}$ trace element solution (Hopwood et al., 1985) per $100 \mathrm{ml} \mathrm{BA}$ and $0.15 \%$ highly cross-linked Remazol-blue-conjugated starch.

Preparation of T. curvata chromosomal DNA. The chromosomal DNA of T. curvata was isolated from fresh mycelium collected from exponential-phase cultures $(30 \mathrm{~h}$ ) by the method described by Hopwood et al. (1985) for isolation of total DNA from streptomycetes. The relative insensitivity of $T$. curvata to digestion by lysozyme prompted us to increase the starting amount of mycelium to $29 \mathrm{~g}$ (wet weight) and proportionally to scale up the volumes of solutions used in particular steps of DNA isolation. The mycelium was digested in buffer containing 10 $\mathrm{mM}$-Tris/ $\mathrm{HCl} \mathrm{pH} \mathrm{8.0,} 0.05 \mathrm{M}$-EDTA and $10.3 \%$ (w/v) sucrose. DNA was precipitated by addition of PEG 6000 $(10 \%, w / v$, final concentration) and after overnight incubation it was collected by gentle centrifugation $(4000 \mathrm{~g}$, $6 \mathrm{~min}$ ).

Cloning manipulation. Linearized BamHI-digested pIJ61 and pIJ487 plasmid vectors were prevented from recircularization by incubation with CIAP $(0.1$ unit per $\mu \mathrm{g}$ plasmid DNA) in $50 \mathrm{mM}-\mathrm{Tris} / \mathrm{HCl}$ buffer $\mathrm{pH} 8.0$ at $30^{\circ} \mathrm{C}$ for $30 \mathrm{~min}$. The reaction was terminated by heating to $68^{\circ} \mathrm{C}$ for $10 \mathrm{~min}$ followed by extraction with neutral phenol/chloroform. Chromosomal DNA of $T$. curvata was partially digested with Sau3AI and 6-12 kb fragments were collected from a $10-30 \%$ sucrose gradient.

The ligation of CIAP-treated vector DNA $(1 \mu \mathrm{g})$ with Sau3AI fragments of chromosomal DNA $(5 \mu \mathrm{g})$ was performed in ligation buffer as described by Hopwood et al. (1985) at a DNA concentration of $50 \mu \mathrm{g} \mathrm{ml}^{-1}$ for $20 \mathrm{~h}$ at $14^{\circ} \mathrm{C}$.

Protoplasting and transformation of S. lividans TK 24 (the host strain) was performed as described by Hopwood et al. (1985). After $18-20 \mathrm{~h}$, thiostrepton was added to a final concentration of $30 \mu \mathrm{g} \mathrm{m} \mathrm{l}^{-1}$ to select plasmidcontaining transformants. For improved regeneration of $S$. lividans TK 24 protoplasts, $0.5 \%$ gelatin was added to the R2YE medium.

Restriction endonuclease mapping. BamHI, BcII, BglII, ClaI, EcoRI, EcoRV, HindIII, PstI, PvuII, SauI, SphI, $X b a I$ and $X h o I$ endonucleases were used to construct the physical map of the cloned fragment and to prepare its 
deletion derivatives. Single and double digestions were performed to establish unambiguous maps of each plasmid. Horizontal agarose gel electrophoresis in TAE and TBE buffers with agarose concentrations of $0.8-1.1 \%$ was as described by Maniatis et al. (1982). גDNA digested with HindIII and PstI was used as a size marker.

Deletion derivatives of plasmid pRS416 were prepared by full or partial cleavage of $1 \mu \mathrm{g}$ plasmid DNA with restriction endonucleases and by ligation with T4 DNA ligase for $16 \mathrm{~h}$ at $14^{\circ} \mathrm{C}$, using a low DNA concentration $\left(5 \mu \mathrm{g} \mathrm{ml}^{-1}\right)$, which favoured recircularization.

Quantitative assay of thermostable $\alpha$-amylase activity. A single sporulating colony of each transformant was inoculated into $80 \mathrm{ml}$ YEME medium (Hopwood et al., 1985) in which sucrose was replaced by $2 \%$ starch or $2 \%$ maltose. After 5-7 d, the culture medium was centrifuged in Eppendorf tubes and 0.1 ml supernatant was made up to $1.0 \mathrm{ml}$ with $10 \mathrm{~mm}$-potassium phosphate buffer $\mathrm{pH} 6.5$. Each sample was preincubated for $10 \mathrm{~min}$ at $67^{\circ} \mathrm{C}$ and, after addition of $\alpha$-amylase assay tablets (Spofa, Czechoslovakia), each sample was incubated for a further $15 \mathrm{~min}$ at the same temperature. The Spofa ALFA-AMYLASE TEST is highly specific towards $\alpha$-amylase so that the presence of glucoamylase and/or other amylolytic enzymes does not interfere with the assay. As a result of the hydrolytic action of $\alpha$-amylase upon the chromogenic starch, water-soluble, dyed maltose-type oligosaccharide fragments were liberated. The reaction was terminated by adding $4 \mathrm{ml}$ stop solution $(10 \mathrm{~g}$ calcium carbonate, $100 \mathrm{ml}$ acetone, $900 \mathrm{ml} \mathrm{H}_{2} \mathrm{O}$ ). The intensity of the released blue colour was measured at $620 \mathrm{~nm}$. The enzyme activity was estimated according to the instructions provided by the supplier.

$S D S-P A G E$ of supernatant proteins. The mycelium was removed by centrifugation and $20 \mathrm{ml}$ portions of the supernatant were treated with ammonium sulphate at $80 \%$ saturation. Precipitated fractions were centrifuged for 10 min at 6000 r.p.m. in a Sorvall RT 6000B (A-500 rotor) and dialysed overnight against 20 vols PBS. The samples were analysed by SDS-PAGE (Laemmli, 1970) using a $5 \%(w / v)$ stacking gel and a $15 \%$ separation gel under nonreducing conditions. Protein bands were visualized by staining with Coomassie Blue R-250.

\section{RESULTS AND DISCUSSION}

\section{Cloning and identification of the tam gene}

To clone the $\alpha$-amylase gene, Sau3AI fragments, approximately $6-12 \mathrm{~kb}$ in size, of chromosomal DNA of $T$. curvata were inserted into BamHI-linearized pIJ61 vector that had been dephosphorylated with CIAP. About 15000 thiostrepton-resistant colonies were obtained after transformation of $S$. lividans TK 24 protoplasts with the ligation mixture. More than $95 \%$ of them were neomycin-sensitive, which indicated a high frequency of insertion in the BamHI site of pIJ61 vector. The sporulating colonies were replica-plated onto BA plates containing Remazol-blue-conjugated starch. One transformant produced a colourless zone around the colony, indicating that it had $\alpha$-amylase activity. Retransformation of the plasmid, termed pRS416, isolated from this transformant confirmed that the thermostable $\alpha$-amylase coding gene, tam, was carried on the plasmid. Thermostability of the $\alpha$-amylase produced by the transformant was tested by transfer to $65^{\circ} \mathrm{C}$ of $\mathrm{BA}$ agar plates with $48 \mathrm{~h}$ colonies grown at $30^{\circ} \mathrm{C}$. At the higher temperature the presecreted thermostable $\alpha$-amylase cleared and enlarged the originally faint zone around the producer colonies, although the Streptomyces transformants were killed at this temperature.

Restriction analysis of isolated plasmid pRS416 revealed an $8.3 \mathrm{~kb}$ DNA insert in the BamHI site of pIJ61 and allowed construction of the restriction map (Fig. 1).

\section{Localization of tam gene by subcloning and deletion procedures}

Two DNA regions, $5.22 \mathrm{~kb}$ and $6.65 \mathrm{~kb}$, located in the left part of the inserted fragment and partially in the adjoining vector molecule were deleted from pRS416 using XhoI as described in Methods. The resulting plasmids, pRS418 and pRS419, having inserts of only 4.31 and $2.87 \mathrm{~kb}$, respectively, could still encode the synthesis of thermostable $\alpha$-amylase (Fig. 1).

The ability to encode production of thermostable $\alpha$-amylase was preserved when fragments of various lengths obtained after digestion of pRS418 and pRS419 with different restriction endonuclease were subcloned in plasmid vectors pIJ622, pRS487 and pRS410. Plasmid pRS417 was constructed by ligation of a $3.0 \mathrm{~kb}$ SstI fragment of pRS419 in the Sst I target site of pIJ622 vector. Plasmid pRS421 was obtained by the insertion of a BamHI-HindIII fragment of pRS418 in the polylinker region of pIJ487, and plasmid pRS422 was obtained by replacing the BamHI$X b a I$ fragment of the aph gene of $\mathrm{pRS} 410$ with the BamHI-XbaI fragment of pRS418. Plasmid pRS420 was prepared by a double digestion of pRS418 with SauI and BamHI, followed by 


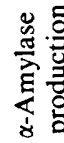
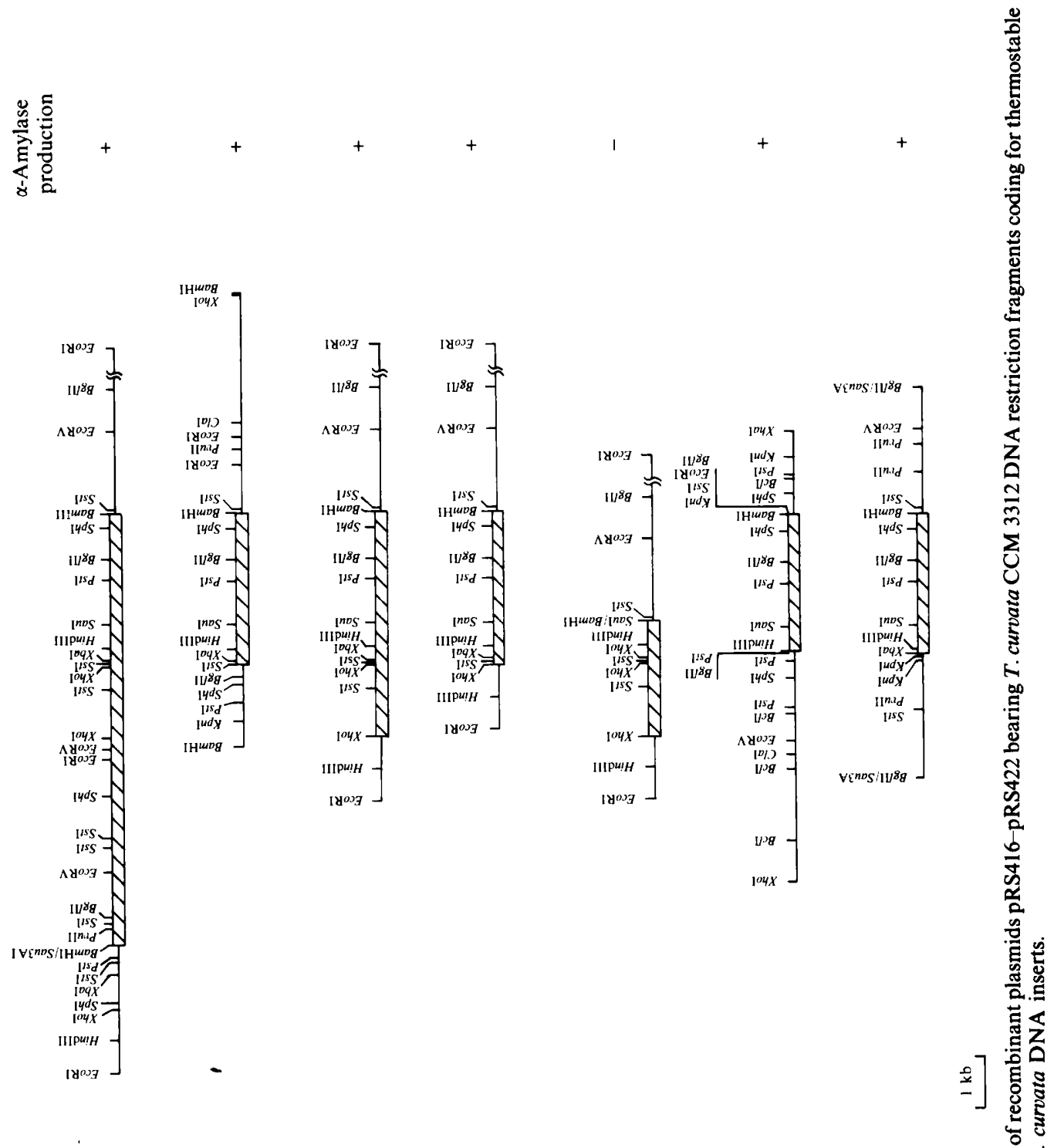

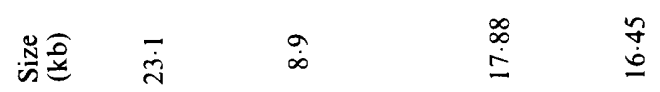

$\stackrel{\infty}{\stackrel{\infty}{i}} \quad \infty$

西

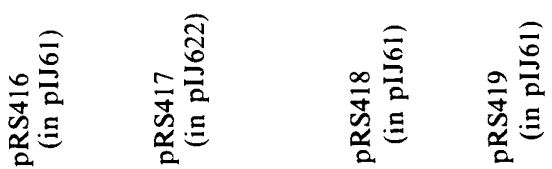

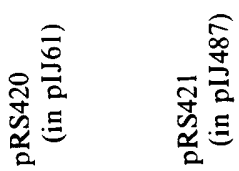

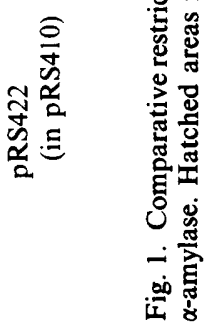




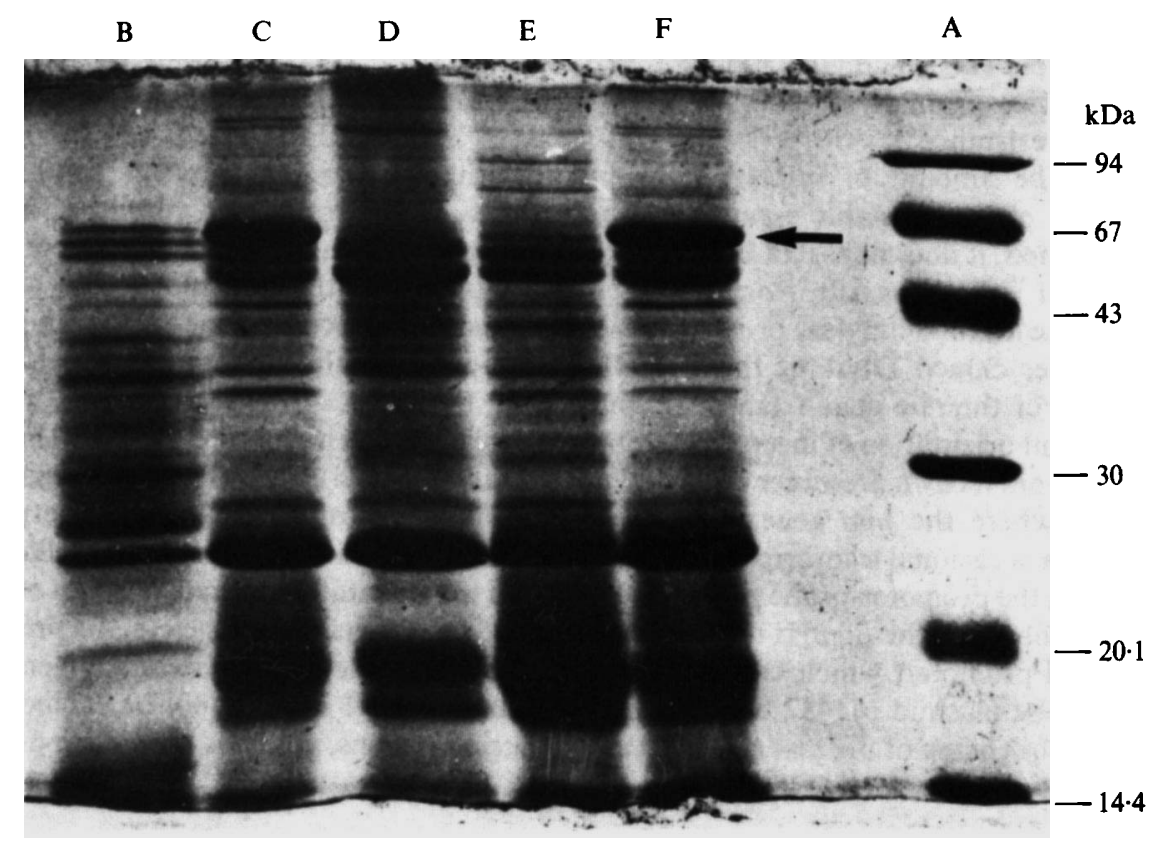

Fig. 2. SDS-PAGE of extracellular proteins from: lane B, $T$. curvata CCM 3325 - amount of applied extracellular proteins $6 \mu \mathrm{g}$; lane C, S. lividans TK 24(pRS416)-7.5 $\mu \mathrm{g}$; lane $\mathrm{D}, S$. lividans TK 24(pIJ61) - 8.5 $\mu \mathrm{g}$; lane E, $S$. lividans TK 24(pRS420)-12.5 $\mu \mathrm{g}$; lane $\mathrm{F}, S$. lividans TK 24(pRS418)-7.5 $\mu \mathrm{g}$. Lane A, Low Molecular Weight Calibration Kit (Pharmacia-LKB): phosphorylase $b, 94 \mathrm{kDa}$; albumin, $67 \mathrm{kDa}$; ovalbumin, $43 \mathrm{kDa}$; carbonic anhydrase, $30 \mathrm{kDa}$; trypsin inhibitor, $20 \cdot 1 \mathrm{kDa} ; \alpha$-lactalbumin, $14.4 \mathrm{kDa}$. The position of $\alpha$-amylase protein is indicated by the arrow.

filling cohesive ends of the plasmid molecule with the aid of dNTPs and Klenow fragment of DNA polymerase and religation of the resulting blunt ends of the plasmid molecule. No thermostable $\alpha$-amylase activity was detected in cells transformed by this plasmid.

Although several taxonomic studies on Thermomonospora have been published, surprisingly none of them has, to our knowledge, included any data about the $G+C$ content of Thermomonospora chromosomal DNA. The percentage of $\mathrm{G}+\mathrm{C}$ in $T$. curvata chromosomal DNA was therefore calculated in this laboratory on the basis of melting temperature of chromosomal DNA in $0.01 \times \mathrm{SSC}(1 \times \mathrm{SSC}$ is $0.15 \mathrm{M}-\mathrm{NaCl}, 0.015 \mathrm{M}$-trisodium citrate, $\mathrm{pH} 7)$. The calculation was performed according to Stackenbrandt \& Kandler (1979); the melting temperatures obtained in two determinations were $82.28{ }^{\circ} \mathrm{C}$ and $81.88{ }^{\circ} \mathrm{C}$. The $\mathrm{G}+\mathrm{C}$ content of Thermomonospora chromosomal DNA thus calculated, $67 \mathrm{~mol} \%$, is quite close to that of streptomycete DNA, 73\% (Benigni et al., 1975) and it is likely that the codon use in both bacteria will be very similar.

The $\alpha$-amylase protein excreted by $S$. lividans TK 24 bearing the tam gene appeared as a $62 \mathrm{kDa}$ band on SDS-PAGE. This size of protein is in good agreement with the molecular mass of the thermostable $\alpha$-amylase protein secreted by $T$. curvata (Glymph \& Stuzenberger, 1977). It is very likely that the signal peptide of proamylase coded by $T$. curvata tam gene is correctly recognized by the $S$. lividans TK 24 host (Fig. 2).

The $\alpha$-amylase activity in the culture medium reached $60 \mu \mathrm{kat} \mathrm{l}^{-1}$, when $S$. lividans TK 24 strains bearing low-copy-number recombinant plasmids pRS416, pRS418 and pRS419 were cultivated in YEME medium (Hopwood et al., 1985) in which sucrose was replaced with $2 \%$ starch or $2 \%$ maltose. However, contrary to expectation, S. lividans TK 24 strains bearing the tam gene subcloned in multicopy plasmids pIJ622, pIJ487 or pRS410 secreted less $\alpha$-amylase in the same medium than did the transformants carrying low-copy-number recombinant plasmids. 
The most likely explanation for this is instability of T. curvata DNA inserts in high-copy-number plasmid vectors. This could be demonstrated by the loss of thermostable $\alpha$-amylase production by many colonies originally bearing pRS417, pRS421 and pRS422 plasmids and still exhibiting thiostrepton resistance.

Although the amount of mRNA hybridizing with the tam gene, and the intracellular concentration of thermostable $\alpha$-amylase in cells containing recombinant plasmids, have not been determined, it does not seem likely that double transcription of the tam gene from its own promoter and simultaneously from the promoter situated in the plasmid vector would be involved in the loss of $\alpha$-amylase production. A similar situation occurs, for example, in pRS416, which includes cloned DNA at the BamHI site of pIJ61 in the orientation which enables transcription of the tam gene from aph promoter.

The different orientation of inserts in recombinant plasmids demonstrates that the tam gene is transcribed from its own promoter region. This conclusion is also confirmed by the construction of pRS421, where the tam gene was inserted behind the strong transcription terminator, preventing an occasional transcription of the tam gene from a plasmid promoter. It follows from the cloning in the promoter-probe plasmid pIJ487 that the orientation of transcription of the tam gene is probably from the BamHI to the HindIII site of the inserts. Nevertheless, the presence of an additional promoter, which can initiate transcription of the promoterless aph gene in the promoter-probe plasmid pIJ487 between the SauI and HindIII sites cannot be excluded. It is hoped that sequencing of the tam gene and neighbouring regions, which is now in progress, will clarify this question.

We gratefully acknowledge the receipt of plasmids and $S$. lividans strains from D. A. Hopwood and M. J. Bibb, Norwich, UK. T. curvata CCM 3312 was from the Czechoslovak Culture Collection and thiostrepton was from S. J. Lucania, Squibb.

\section{REFERENCES}

Bellamy, W. D. (1974). Single cell proteins from cellulose wastes. Biotechnology and Bioengineering 16, 869-880.

Bellamy, W. D. (1977). Cellulose and lignocellulose digestion by thermophilic actinomyces for single-cell protein production. Developments in Industrial Microbiology 18, 249-254.

Benigni, R., Antonov, P. P. \& Carere, A. (1975). Estimate of the genome size by renaturation studies in Streptomyces. Applied Microbiology 30, 324 336.

Bibb, M. J., Jones, G. H., JosepH, R., ButtNer, M. J. \& WARD, J. M. (1987). The agarase gene of Streptomyces coelicolor A3(2): affinity purification and characterization of the cloned gene product. Journal of General Microbiology 133, 2089--2096.

ButTner, M. J., FeARnLey, I. M. \& BiBB, M. J. (1987). The agarase gene (dag) of Streptomyces coelicolor A3(2): nucleotide sequence and transcriptional analysis. Molecular and General Genetics 209, 101109.

Crawford, D. L., McCoy, E., Harkin, J. M. \& JONES, P. (1973). Production of microbial protein from waste cellulose by Thermomonospora fusca, a thermophilic actinomycete. Biotechnology and Bioengineering 25, 833-843.

Ghangas, G. S. \& WiLson, D. B. (1987). Expression of a Thermomonospora fusca cellulase gene in Streptomyces lividans and Bacillus subtilis. Applied and Environmental Microbiology 53, 1470-1475.

Ghangas, G. S. \& Wilson, D. B. (1988). Cloning of the Thermomonospora fusca endonuclease E2 gene in Streptomyces lividans: affinity purification and functional domains of the cloned gene product. Applied and Environmental Microbiology 54, 2521-2526.
Glymph, J. L. \& StuZenberger, F. J. (1977). Production, purification and characterization of $\alpha$ amylase from Thermomonospora curvata. Applied and Environmental Microbiology 34, 391-397.

GoOdFellow, M. \& CROSS, T. (1984). Classification in The Biology of Actinomycetes, pp. 8-164. Edited by M. Goodfellow, M. Mordarski \& S. T. Williams. London: Academic Press.

Hägerdal, B., Ferchak, J. D. \& Pye, E. K. (1980). Saccharification of cellulose by the cellulolytic enzyme system of Thermomonospora sp. 1. Stability of cellulolytic activities with respect to time, temperature and $\mathrm{pH}$. Biotechnology and Bioengineering 22, 1515-1526.

Hopwood, D. A., Bibb, M. J., Chater, K. F. Kieser, T., Bruton, C. J., Kieser, H. M., LydiATE, D. J., SMITH, C. P., WARD, J. M. \& SCHREMPF, H. (1985). Genetic Manipulation of Streptomyces: a Laboratory Manual. Norwich, UK: John Innes Foundation.

Hoshiko, S., Makabe, O., Nojiri, C., Katsumata, K., SATOH, E. \& NaGaOKA, K. (1987). Molecular cloning and characterization of the Streptomyces hygroscopicus $\alpha$-amylase. Journal of Bacteriology. 169 , 1029-1036.

IWASAKI, A., Kishida, H. \& OKanishi, M. (1987). Molecular cloning of a xylanase gene from Streptomyces no. 36a and its expression in Streptomyces lividans 66. Journal of Antibiotics 39, 985-993.

Kendall, K. \& Cullum, J. (1984). Cloning and expression of an extracellular agarase gene from Streptomyces coelicolor A3(2) in Streptomyces lividans 66. Gene 29, 315-321.

LAEMMLI, U. K. (1970). Cleavage of structural proteins during the assembly of the head of bacteriophage T4. Nature, London 227, 680-685. 
Long, C. M., Virolle, M. J., Chang, S. Y., Chang, S. \& BIBB, M. J. (1987). $\alpha$-amylase gene of Streptomyces limosus: nucleotide sequence, expression motifs, and amino acid sequence homology to mammalian and invertebrate $\alpha$-amylase. Journal of Bacteriology 169 , 5745-5754.

Maniatis, T., Fritsch, E. F. \& Sambrook, J. (1982). Molecular Cloning, a Laboratory Manual. Cold Spring Harbor, NY: Cold Spring Harbor Laboratory.

MCKillop, C., Elvin, P. \& Kenten, J. (1986). Cloning and expression of an extracellular $\alpha$-amylase gene from Streptomyces hygroscopicus in Streptomyces lividans 66. FEMS Microbiology Letters 36, 3-7.

Pidcock, K. A., Montenecourt, B. S. \& Sands, J. A. (1985). Genetic recombination and transformation in protoplasts of Thermomonospora fusca. Applied and Environmental Microbiology 50, 693-695.

Robins, P. W., Wirth, D. F. \& Hering, C. (1981). Expression of Streptomyces enzyme endoglycosidase $\mathrm{H}$ in Escherichia coli. Journal of Biological Chemistry 256, 10640-10644.

Shareck, F., Mondou, F., Morosolli, R. \& KluemPFEL, D. (1987). Cloning of DNA sequences involved in overproduction of endoglucanase activity in Streptomyces lividans 66. Biotechnology Letters 9, 169-174.

StackebrandT, E. \& Kandler, O. (1979). Taxonomy of the genus Cellulomonas based on phenotypic characters and deoxyribonucleic acid-deoxyribonucleic acid homology, and proposal of seven neotype strains. International Journal of Systematic Bacteriology 29, 273-282.

Stackebrant, F. \& Schleifer, K.-H. (1984). Molecular systematics of Actinomycetes and related organisms. In Biological, Biochemical and Medical Aspects of Actinomycetes, pp. 485-504. Edited by Z. OrtizOrtiz, L. F. Bojalil \& V. Yakoleff. Orlando: Academic Press.

Stuzenberger, F. \& Carnell, R. (1977). Amylase production by Thermomonospora curvata. Applied and Environmental Microbiology 34, 234-236.

Thompson, C. J., Kieser, T., WaRD, J. M. \& HoPwOOD, D. A. (1982). Physical analysis of antibiotic resistance genes from Streptomyces and their use in vector construction. Gene 20, 51-62.

Virolle, M.-J. \& BibB, M. J. (1988). Cloning, characterization and regulation of an $\alpha$-amylase gene from Streptomyces limosus. Molecular Microbiology 2, 197-208.

Ward, J. M., JANSEN, G. R., KIESER, T., BibB, M. J., Buttner, M. J. \& BibB, M. J. (1986). Construction and characterization of a series of multicopy promoter-probe plasmid vectors for Streptomyces using the aminoglycoside phosphotransferase gene from $\mathrm{Tn} 5$ as indicator. Molecular and General Genetics 203, 468-478. 